\title{
Identification of Potential Phytoaccumulator Plants from Tailings Area as a Gold Phytomining Agent
}

\author{
Riky Kurniawan ${ }^{1}$, Hamim² ${ }^{2 *}$, Cynthia Henny ${ }^{3}$, Awalina Satya ${ }^{3}$ \\ 1 Graduate student, Department of Biology, Faculty of Mathematics and Natural Sciences, IPB University, \\ Bogor 16680, Indonesia \\ 2 Department of Biology, Faculty of Mathematics and Natural Sciences, IPB University, Bogor 16680, \\ Indonesia \\ 3 Research Center for Limnology, National Research and Innovation Agency Republic of Indonesia, \\ Bogor 16911, Indonesia \\ * Corresponding author's email: hamim@ipb.ac.id
}

\begin{abstract}
Indonesia comprises a high diversity of plant species, some of which may have a potential role as metal phytoaccumulators including gold $(\mathrm{Au})$, known as phytomining agents. Some local plants grown at the metal-contaminated sites can become potential phytoaccumulators due to their adaptation capability to the metal-polluted conditions. Phytomining is one of the eco-friendly methods usually used to extract lowgrade metal bio-ore from the environment and this method can be applied on gold tailing waste. This study aimed to find the hyperaccumulator plants selected from a gold mine area, which can be applied for a gold ( $\mathrm{Au}$ ) phytomining agent. The study was located in Aneka Tambang Inc. (PT. ANTAM-UBPE Pongkor), Bogor, West Java, Indonesia. A vegetation analysis was carried out using a transect experiment on the area around gold mine tailings dam, and the samples were collected for further analysis. Tailings were sampled for metal analysis, while the plant samples including the below-ground and above-ground part of biomass were separated, washed, and weighed for the biomass and metal analyses. The total concentration of gold in the plants and tailings was measured by using a graphite furnace atomic absorption spectrophotometer (GF-AAS). There were 17 plant species identified as gold accumulators collected from the gold mine tailing area, which were potential phytomining agents. The gold measurement showed that all plants species had the ability to absorb gold residues from the tailings dam, indicating that all the plants have a potential role as gold phytoaccumulators. Among the species, Typha angustifolia had the highest importance value index (IVI) followed by Cyperus haspan. The results showed that T. angustifolia and C. haspan were among the plants with the highest potential as Au phytoaccumulators to support the gold phytomining program for the gold mine tailing area.
\end{abstract}

Keywords: phytoaccumulator, gold phytomining, gold-mine tailings, Typha angustifolia, Cyperus haspan

\section{INTRODUCTION}

Indonesia is among the countries characterized with mega biodiversity, including plant species. Many types of plants have the potential capability as phytoaccumulators of metal. A phytoaccumulator is a plant that has the capability to absorb contaminants in the soil, transport them through the roots, and then accumulate them in other parts of the plant (Tangahu et al., 2011). Certain plants (hyperaccumulators) can absorb certain metals in high amounts with a relatively short period. Hence, these plants can be used as phyomining agents. A phytomining agent usually should be chosen from local plants grown naturally around the metal-contaminated sites, because these plant species have already adapted to polluted conditions for a long time (Wolfe \& Bjornstad, 2002). Phytomining is an economically and environmentally friendly technology in comparison to heap leaching. Phytomining also has the potential to allow economic exploitation 
of low grade ores or mineralized soils that are too poor for conventional mining operation (Sheoran et al., 2013).

In the area of gold mining, the high content of heavy metals in tailings is one of the greatest problems of contaminants that have a negative impact on organisms including the plants around the contaminated areas, such as the tailings dam. Fashola et al. (2016) explained that the tailings produced from gold processing contain high amounts of heavy metals due to various metal-containing materials resulting from the separation and purification of gold. Hilmi et al. (2018) for example, found that lead $(\mathrm{Pb})$ is among the non-essential heavy metals contained in gold mine tailing waste with considerably high concentration.

There are two types of ore in primary gold mining activities: the ore with high and low gold concentrations (Alimano \& Rinjani, 2017). Recently, even though the mining technology has been much more advanced, it still cannot extract $100 \%$ of the gold stored in minerals/sediments (Sheoran et al., 2009). Recovering the remaining gold stored in tailing waste requires advanced technology that is costly and inefficient.

Plants can absorb and accumulate gold from their surrounding environment. Gold phytomining is an eco-friendly method to extract lowgrade bio-ore from minerals/sediments or tailing waste. Phytomining can also recover other metals such as silver, nickel, platinum, and palladium (Rodriguez et al., 2007). Several types of plants have been widely known to have the ability to absorb and accumulate gold, such as Helianthus annuus, Brassica juncea, Medicago sativa, Zea mays, Nicotiana tabacum, Vetiveria zizanioides, Alocasia macrorhizos, and Ipomoea batatas (Noviardi et al., 2021; Saim et al., 2020; Alimano \& Rinjani, 2017; Krisnayanti et al., 2016; Wilson-Corral et al., 2011; Bali et al., 2010; Marshall et al., 2007).

Many studies have been carried out on the phytomining of other metals, such as nickel (Ni). These days, more than 700 hyperaccumulators have been described, more than $80 \%$ of them accumulating nickel (Jaffre et al., 2018). However, the study on gold phytomining is still limited, especially by utilizing some weeds grown on the gold mine area. The purpose of this study was to identify the local plants in the area around the tailings dam that can absorb and accumulate high amounts of gold metal in order to be applied for gold phytomining.

\section{MATERIALS AND METHODS}

\section{Study site}

The materials (plants and gold mine tailings) used in the study were collected from the area around tailings dam of PT Aneka Tambang (ANTAM) UBPE Pongkor, Nanggung District, Bogor Regency, West Java, Indonesia. ANTAM Inc. is a national mining company that processes several minerals in Indonesia. The location of samples collection in ANTAM UBPE Pongkor was specified by latitude: $6^{\circ} 39^{\prime} 44^{\prime \prime} \mathrm{S}$ and longitude: $106^{\circ}$ 35 ' 6" E. The specific location of the tailings dam can be seen in the Figure 1 .

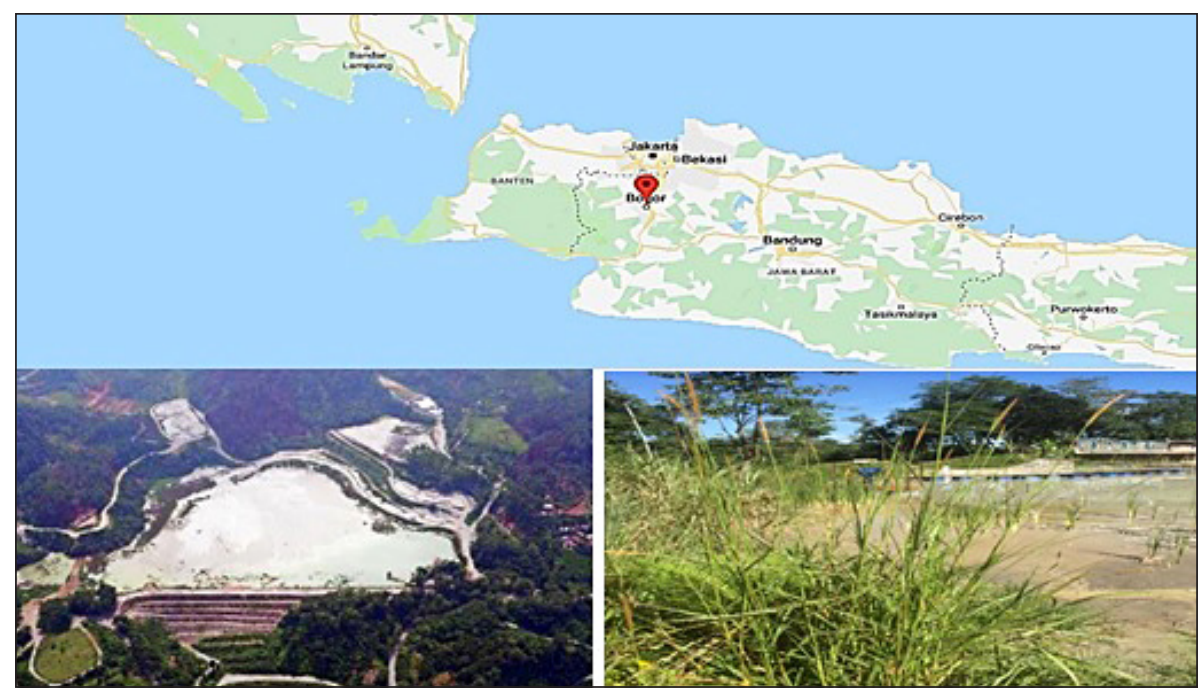

Figure 1. Sampling location of the plants in tailings dams of PT. Aneka Tambang (ANTAM Inc), UBPE Pongkor, Bogor Regency, West Java, Indonesia 


\section{Sampling of plants and gold tailing waste}

This research was conducted from November 2019 to May 2020. The plants and gold tailing waste were collected from the area around the tailings dam in PT Aneka Tambang (ANTAM Inc.). Three stations were selected to collect samples. The line transect method was applied to retrieve the plant samples. Three lines transect (each with a length of 9 meters) with plot sized $3 \times 3$ meters were established in the area around the tailings dam (front area, middle area, and back area), with three replications. The identification of plants and the analysis of plant physiology were conducted at the Plant Physiology and Genetics Laboratory, Department of Biology, IPB University, Bogor, Indonesia.

\section{Plant communities analysis}

The plant community analysis was carried out to measure frequency, density, important value index (IVI), and species diversity index (H'). The IVI value (Understory plant) was obtained from the density and frequency values of the plant species (Odum 1971).

$$
\begin{gathered}
\text { IVI }(\text { Understory plant })= \\
\text { Frequency relative }+ \text { Density relative }
\end{gathered}
$$

While, the criteria for species diversity index value (H') are as follows (Magurran 1988):

- H'> 3: The diversity index categorized as high,

- $1 \leq \mathrm{H}^{\prime} \leq 3$ : The diversity index categorized as medium,

- $\mathrm{H}^{\prime}<1$ : The diversity index categorized as low.

\section{Plant growth analysis}

Plant growth was analyzed by measuring shoot length, root length, shoot dry weight, and root dry weight. The dry weight of shoots and roots was measured after the plants were dried in an oven at $70{ }^{\circ} \mathrm{C}$ for $4-5$ days.

\section{MDA analysis}

Malondialdehyde (MDA) levels were determined as an indication of oxidative stress levels in a plant. The MDA analysis was measured using the formula (Wang et al. 2013):

$$
\begin{gathered}
M D A\left(\mu \mathrm{mol} \mathrm{mL} L^{-1} B B\right)= \\
=6.45 \times\left(A_{532}-A_{600}\right)-0.56 \times A_{4}
\end{gathered}
$$

MDA : malonedialdehyde levels

$A_{450} \quad$ : absorbance at wavelenght $(\lambda) 450 \mathrm{~nm}$

$A_{532} \quad$ : absorbance at wavelenght $(\lambda) 532 \mathrm{~nm}$

$A_{600} \quad$ : absorbance at wavelenght $(\lambda) 600 \mathrm{~nm}$

\section{Gold analysis}

All local plants were harvested, and then the plant shoots and roots were separated, washed, and weighed. The harvested plants were dried in the oven for 72 hours at $70{ }^{\circ} \mathrm{C}$. In order to analyze gold in tailings and plants, $0.5 \mathrm{gr}$ subsamples were digested using a mixture of $5 \mathrm{ml}$ aqua regia, $10 \mathrm{ml}$ nitric acid, and $5 \mathrm{ml}$ hydrogen peroxide. Then, the gold content was analyzed by using a Graphite Furnace-Atomic Absorption Spectrophotometer (Hitachi Instrument Company Z 2700 series). The gold concentration in each sample was measured in triplicate, and the average values were reported.

\section{Data analysis}

\section{Biological concentration factor and translocation factor}

The analysis of biological concentration factor (BCF) and translocation factor (TF) are important calculated values to determine the accumulation of gold uptake and distribution in plant tissues. The BCF value represents a plant's ability to accumulate metals into its tissues from the soil or surrounding environment. The BCF value was calculated as the ratio of the total gold concentration in plant roots to the total gold concentration in the soil/sediment as shown in equation 3 (Herlina et al., 2020; Yoon et al., 2006).

$$
B C F=[A u] \text { roots } /[\mathrm{Au}] \text { soil }
$$

Where $[\mathrm{Au}]$ roots was the total gold concentration in the roots, and $[\mathrm{Au}]$ soil was the total gold concentration in the soil. The criteria for BCF value are as follows (Wei et al., 2008; Malayeri et al., 2008):

- The BCF values of 1 to 10 indicate high accumulator plants (hyperaccumulators),

- The BCF values of 0.1 to 1 indicate medium accumulator plants,

- The BCF values of 0.01 to 0.1 indicate low accumulator plants,

- The BCF values $<0.01$ indicate non-accumulator plants. 
The translocation factor (TF) is used to evaluate the phytoextraction potential of a plant. The TF value was calculated as the ratio of metal concentration in the shoots to metal concentration in the roots as shown in equation 4 (Herlina et al., 2020; Yoon et al., 2006).

$$
T F=[A u] \text { shoots } /[\mathrm{Au}] \text { roots }
$$

$[\mathrm{Au}]$ shoots was the total gold concentration in the above-ground part biomass, whereas [Au] roots was the total gold concentration in the below-ground part biomass. The categories for TF value are as follows (Majid et al., 2014):

- The $T F$ value $<1$ : phytostabilization mechanism,

- The $T F$ value $>1$ : phytoextraction mechanism.

\section{Potential of phytomining}

The potential of phytomining (PP) on gold metal uptake in the environment can be calculated from the total amount of gold metal in plant and dry weight biomass of plant per hectare (Chaney \& Baklanov, 2017). The potential of phytomining calculation was as follows:

$$
\begin{gathered}
P P=[A u] \text { total gold in plant } \times \\
{[\text { Dry Weight Biomass }] \text { plant }}
\end{gathered}
$$

Where $[\mathrm{Au}]$ total gold was the total gold concentration in the above-ground, and belowground part ( $\mathrm{mg} / \mathrm{kg})$, and [Dry Weight Biomass] plant was the dry weight biomass of plant were harvested ( $\mathrm{t} / \mathrm{ha}$ ). In addition, for the dry weight biomass estimation obtained from the calculation of planting with a spacing $5 \times 10 \mathrm{~cm}^{2}$.

\section{Statistical analysis}

The data summary and calculations were performed using Microsoft Excel. The statistical analysis was carried out using a one-way analysis of variance (ANOVA). The difference between treatment means was determined by Duncan's multiple range test (DMRT) at a 5\% level $(\mathrm{P}>0,05)$ using SPSS version 26 software.

\section{RESULT AND DISCUSSION}

\section{Plants composition and communities}

On the basis of the vegetation analysis, there were a total of 17 species and 9 families obtained at the selected study sites. The total number of plants found in the transects were 1014 individuals and the species with the highest number of individuals were Typha angustifolia (264 individuals), Cyperus compactus (230 individuals), and Leersia hexandra (200 individuals), respectively, while other species were fewer than 100 individuals (Figure 2). Setyaningsih et al. (2018) also observed that $T$. angustifolia was the most dominant plant and grew well in the gold mine tailing area and had a potential role in the phytoremediation process. The results indicated that $T$. angustifolia had high tolerance to all environmental factors in gold mining areas, including higher heavy metals. A previous study also suggested that T. angustifolia had the ability to be used for phytoremediation of the wastewater containing mercury (Hg) (Rondonuwu, 2014).

On the basis of on the habitus inventory, the plants found in the transects were predominated by understory plants (herbs, shrubs, lianas) with herbaceous species as the most common (Figure 3A). Greater presence of the understory plants at the tailings dam location were probably due to its open ecosystem conditions (no shade plants or trees). The three highest proportions of the nine families found in the location belonged to Poaceae and Cyperaceae (each with 4 species),
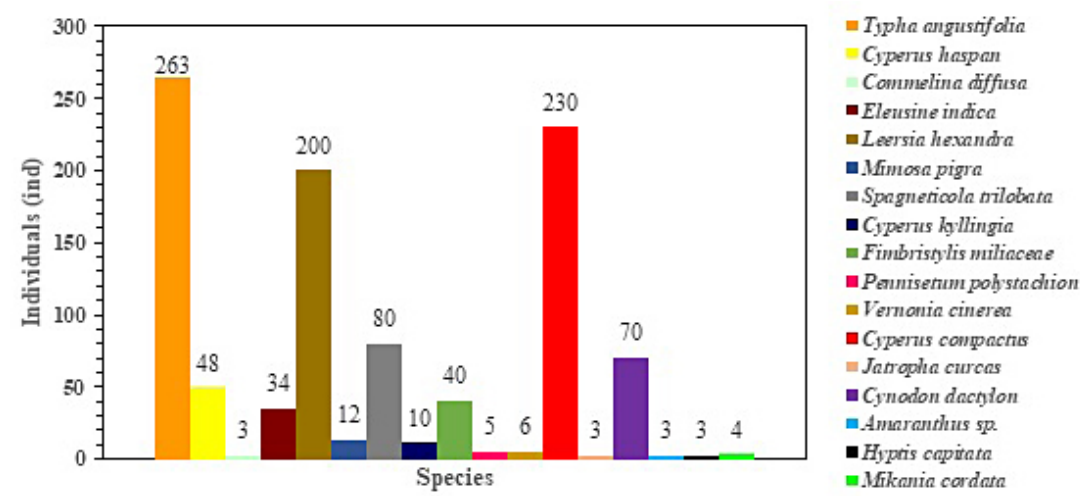

Figure 2. Plant species and number of individuals found in the area around the tailings dam 
followed by Asteraceae (3 species) (Figure 3B). Some species under the family of Poaceae have high adaptability, are widely distributed, and able to grow on dry and flooded land (Aththorick, 2005). According to Guerra-Sierra (2021) some families such as Euphobiaceae, Asteraceae, Cyperaceae, Fabaceae, Poaceae, Lamiaceae, and Caryophyllaceae have the ability to accumulate heavy metal in the tropical area.

For further analysis, the data of density, frequency, important value index, and species diversity index are presented in Table 1. Among the species, $T$. angustifolia and $C$. haspan clearly had the highest relative frequency with the value of more than 10, while the others were less than 10. The results indicated that these two species were more evenly distributed than others and the plants adapted very well in the area around gold mine tailings dam. A species or organism that is widely distributed usually has a high frequency of encounters (Indriyani et al., 2017). The highest relative density value was obtained by $T$. angustifolia, C. compactus, and L. hexandra. Highdensity value describes that a plant species has a high adjustment pattern. Thus, the results indicated that those species had a high adaptation pattern to the surrounding environment studied. On the other hand, 5 plant species had lowest-density values, such as C. diffusa, P. polystachion, J. curcas, Amaranthus sp., and H. capitata (Table 1).

Importance value index (IVI) demonstrates the role of the plant species in the study area. The results showed that the plants with higher IVI values was obtained by $T$. angustifolia, $C$. compactus, and $L$. hexaandra with IVI values of 46.14 , 30.27 , and 27.30 , respectively, while others only had the IVI values of less than 20 (Table 1). This indicates that those three plants have the most important role in their community because they have higher IVI values (Asmayannur et al., 2012). On the other hand, the plants with the lowest IVI were C. diffusa, P. polystachion, J. curcas, Amaranthus sp., and H. capitata.

The species diversity index (H') calculated from the study area was around $2.01\left(1 \leq \mathrm{H}^{\prime} \leq 3\right)$, indicating that the diversity index was categorized as medium (Magurran, 1988). With this value, the condition of the ecosystem was also medium, even though there were indications of ecological stresses because of the heavy metals resulting from the tailings. The previous experiment found that the soil in this area contains high metals, poor organic matter, and lower content of macronutrients (Setyaningsih et al., 2018). Apparently, only certain plant species have the capability to adapt and survive under these conditions. Species diversity is a characteristic of community-level and structure. The community has a high species diversity if the community comprises many species. Conversely, a community with low species diversity comprises only a few species. Diversity has the most significant value if all individuals come from different genera or species, while the lowest value is obtained by one genus or only one species (Setiawan et al., 2017).

\section{Plant Growth}

Plant growth was observed according to several specific parameters, including shoots length, roots length, shoots dry weight, and roots dry weight. As shown in Figure 4, the results revealed that $T$. angustifolia had the highest shoots length $(190 \mathrm{~cm})$, while $E$. indica had the highest roots length $(18.5 \mathrm{~cm})$ compared to other species. The roots growth is a standard parameter of plant physiological response to their environment, including metal stressed one, because it is

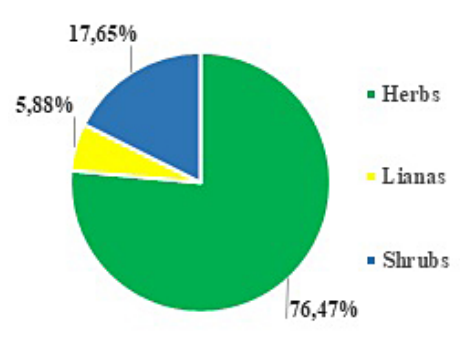

(A)

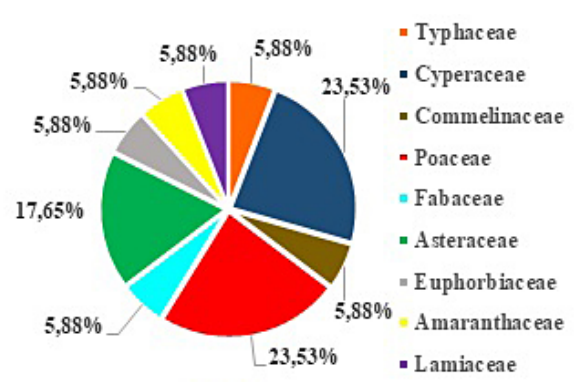

(B)

Figure 3. Percentage of plant habitus, and plant families grew on the transects collected from the area around gold mine tailings dam which comprised three habitus and nine families. A. Percentage of plant habitus, and B. Percentage of plant families 
Table 1. Analysis of plant communities from the transects in the area around the tailings dam

\begin{tabular}{|l|c|c|c|c|c|c|}
\hline \multicolumn{1}{|c|}{ Species } & Frequency & $\begin{array}{c}\text { Frequency } \\
\text { relative }\end{array}$ & Density & Density relative & $\begin{array}{c}\text { Importance } \\
\text { value index }\end{array}$ & $\begin{array}{c}\text { Species } \\
\text { diversity index }\end{array}$ \\
\hline Typha angustifolia & 0.89 & 20.02 & 3.26 & 26.14 & 46.14 & 0.3505 \\
\hline Cyperus compactus & 0.33 & 7.51 & 2.84 & 22.77 & 30.27 & 0.0123 \\
\hline Leersia hexandra & 0.33 & 7.51 & 2.47 & 19.80 & 27.30 & 0.1465 \\
\hline Cyperus haspan & 0.56 & 12.51 & 0.60 & 4.85 & 17.35 & 0.1163 \\
\hline Cynodon dactylon & 0.22 & 5.01 & 0.86 & 6.93 & 11.93 & 0.3366 \\
\hline Fimbristylis miliaceae & 0.33 & 7.51 & 0.49 & 3.96 & 11.46 & 0.0262 \\
\hline Eleusine indica & 0.33 & 7.51 & 0.43 & 3.47 & 10.97 & 0.3203 \\
\hline Spagneticola trilobata & 0.11 & 2.50 & 0.99 & 7.92 & 10.42 & 0.2005 \\
\hline Mimosa pigra & 0.33 & 7.51 & 0.16 & 1.29 & 8.79 & 0.0559 \\
\hline Vernonia cinerea & 0.22 & 5.01 & 0.06 & 0.50 & 5.50 & 0.1276 \\
\hline Cyperus kyllingia & 0.11 & 2.50 & 0.14 & 1.09 & 3.59 & 0.0491 \\
\hline Mikania cordata & 0.11 & 2.50 & 0.04 & 0.30 & 2.80 & 0.0123 \\
\hline Jatropha curcas & 0.11 & 2.50 & 0.02 & 0.20 & 2.70 & 0.0123 \\
\hline Amaranthus sp. & 0.11 & 2.50 & 0.02 & 0.20 & 2.70 & 0.1847 \\
\hline Commelina diffusa & 0.11 & 2.50 & 0.02 & 0.20 & 2.70 & 0.0123 \\
\hline $\begin{array}{l}\text { Pennisetum } \\
\text { polystachion }\end{array}$ & 0.11 & 2.50 & 0.02 & 0.20 & 2.70 & 0.0262 \\
\hline Hyptis capitata & 0.11 & 2.50 & 0.02 & 0.20 & 2.70 & 0.0172 \\
\hline
\end{tabular}

closely related to the disruption of cell activity and plant metabolism (Asati et al., 2016). Roots are a part of plants that interacts directly with the heavy metal stress from the environment. Shahid et al. (2015) explained that heavy metals could harm the roots growth and development, e.g. resulting in inhibiting root growth, root differentiation, root cells damage, and even root cells death. The growth of plant roots and shoots is mostly inhibited by the waste containing heavy metals, due to their toxicity even in small amounts (Asati et al., 2016; Hamim et al., 2017a). In corn, for example, Ghani (2010) reported that the effect of heavy metals $(\mathrm{Cd}, \mathrm{Cr}$, $\mathrm{Co}, \mathrm{Mn}$, and $\mathrm{Pb}$ ) significantly reduced the growth and protein content of the seeds. The increase in essential and non-essential heavy metals above the optimal limit triggers a decrease in growth through the photosynthesis rate inhibition, water and nutrients uptake, as well as enzyme activity inhibition (Asati et al., 2016).

As shown in Figure 5, the results revealed that the highest shoots dry weight was found in the T. angustifolia species followed by C. haspan, while the highest roots dry weight was found in the E. indica species. The plant growth is among the indications of plant adaptability to the area of gold mine tailing. Lead is one of the most toxic elements found in high degree in gold mine tailings (Hilmi et al., 2018). The growth and biomass of these species, suggesting their capacity to adapt and grow under these hard conditions, and therefore the capacity to produce higher biomass and their domination, becomes important to determine their capacity as a phytomining agent. Among the species, T. angustifolia and C. haspan, were the most prospective due to their higher biomass and their other superior parameters (Table 1, Figure 4).

\section{Malondialdehyde levels}

The malondialdehyde (MDA) levels indicate the oxidative stress levels in a plant resulting from the lipid peroxidation process in membranes $(\mathrm{Hu}$ et al., 2012; Hamim et al., 2017b). Increasing the MDA levels indicates that a plant is facing a stress condition. The presence of metals in the plants due to high heavy metal exposure in the media will increase reactive oxygen species (ROS) or oxygen radicals that cause membrane cell damage and impact increasing MDA production in the membrane (Wang et al., 2013). Increased levels of MDA are related to elevated concentrations of heavy metals in plants.

The analysis of MDA content in the shoot from 17 species showed that Amarantus sp. and M. cordata had the highest MDA content (MDA $>1$ ) of $1.95 \mathrm{~mol} / \mathrm{g}$ and $1.25 \mathrm{~mol} / \mathrm{g}$, respectively. This indicated that the two species were experiencing higher oxidative stress than the other species. In turn, $C$. dactylon had the lowest shoots MDA levels which amounted to only $0.19 \mathrm{~mol} / \mathrm{g}$. 


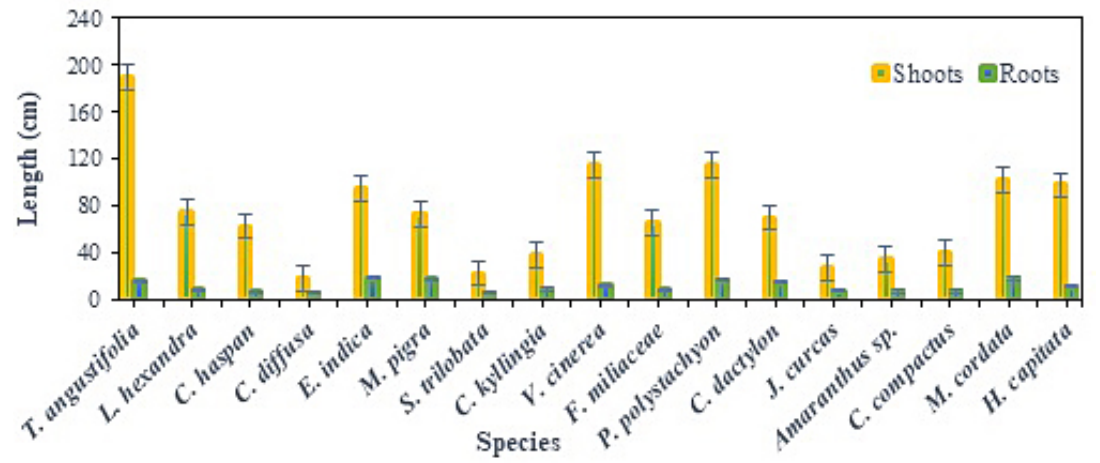

Figure 4. The average of shoot and root length of the plants in the area around the tailings dam

Some experiment recorded that increasing the concentration of metal such as lead was directly proportional to the increase in the MDA level in the plants such as in spinach and wheat, Jatropha and Philippine Tung (Andriya et al., 2019; Hilmi et al., 2018; Lamhamdi et al., 2010). Gill and Tuteja (2010) explained that increasing levels of heavy metals such as gold $(\mathrm{Au})$, silver $(\mathrm{Ag})$, lead $(\mathrm{Pb})$, cadmium $(\mathrm{Cd})$, and mercury $(\mathrm{Hg})$ in a plant significantly raised the production of reactive oxygen species (ROS). These conditions may have induced the damage of membrane indicated by the increase of MDA production as a compound resulting from lipid peroxidation processes. The lower MDA content of other species probably became good indication of their adaptability to their unfavorable environment.

\section{Gold metal concentration in plants}

The analysis of gold content from 17 plant species in the transects indicated that all the plants were able to accumulate the gold from gold tailing waste, although there were differences among the species (Figure 7). Anderson et al. (2005) suggested that the plants will be categorized as gold hyperaccumulator if they can accumulate gold in their tissues at least $1 \mathrm{mg}$ per kilogram (ppm) of gold.

The results showed that the concentration of gold in the shoot samples ranged from 436.09 to $634.55 \mu \mathrm{g} / \mathrm{kg}$ dry weight (with the average of $541.96 \mu \mathrm{g} / \mathrm{kg}$ dry weight), while in the root samples it ranged from 443.24 to $758.33 \mu \mathrm{g} / \mathrm{kg}$ dry weight (with the average of $546.86 \mu \mathrm{g} / \mathrm{kg}$ dry weight) (Figure 7). The average gold content in the plant samples ranged from 478.99 to $667.50 \mu \mathrm{g} / \mathrm{kg}$ dry weight ( $544.41 \mu \mathrm{g} / \mathrm{kg}$ dry weight in average). Amaranthus sp. had the highest total concentration of gold (with the average of $667.5 \mu \mathrm{g} / \mathrm{kg}$ dry weight). In contrast, $P$. polystachion appeared to have the lowest total concentration of gold (with the average of $478.9 \mu \mathrm{g} / \mathrm{kg}$ dry weight). The concentration of gold accumulated by plants was relatively low and under the criteria of the plant categorized as hyperaccumulator plants based on Anderson et al. (2005). So far, the studies reporting about gold phytomining using Amaranthus sp. are still rare, but Pranoto \& Budianta (2020) conducted that a study using Amaranthus spinosus and Jatropha curcas, suggesting that these plants had the capability to absorb lead and arsenic very well. Another study in the gold mine area, Central Kalimantan, Indonesia, Sunariyati

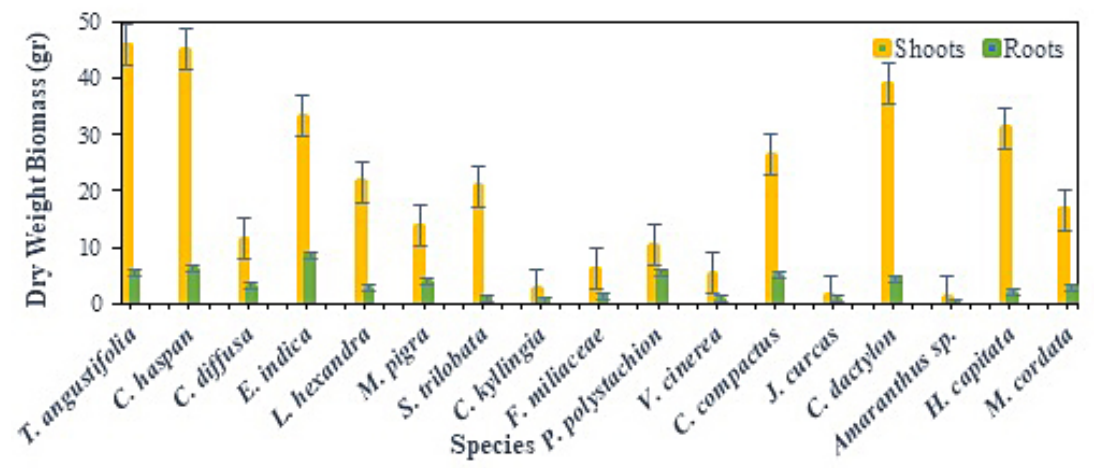

Figure 5. The average of shoot and root dry weight of the plants in the area around the tailings dam 


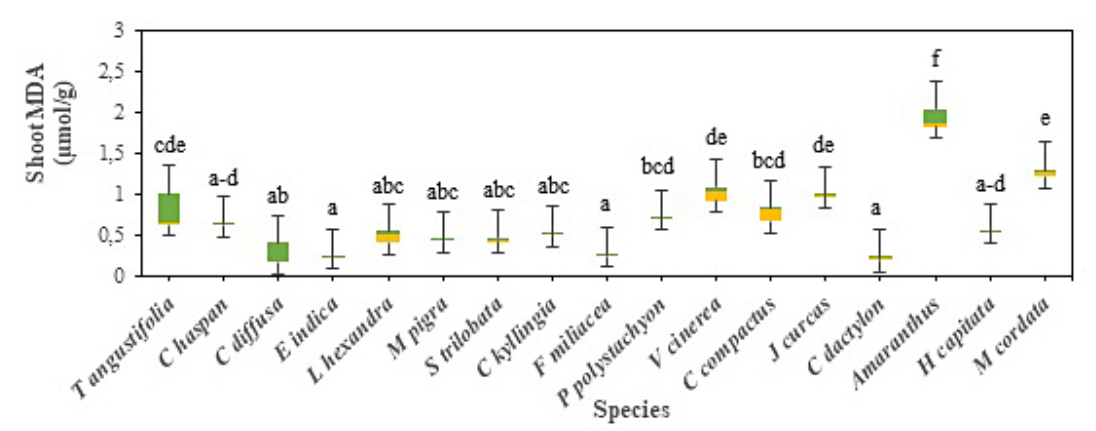

Figure 6. Box-plot graph of plants shoot MDA level in the area around tailings dam
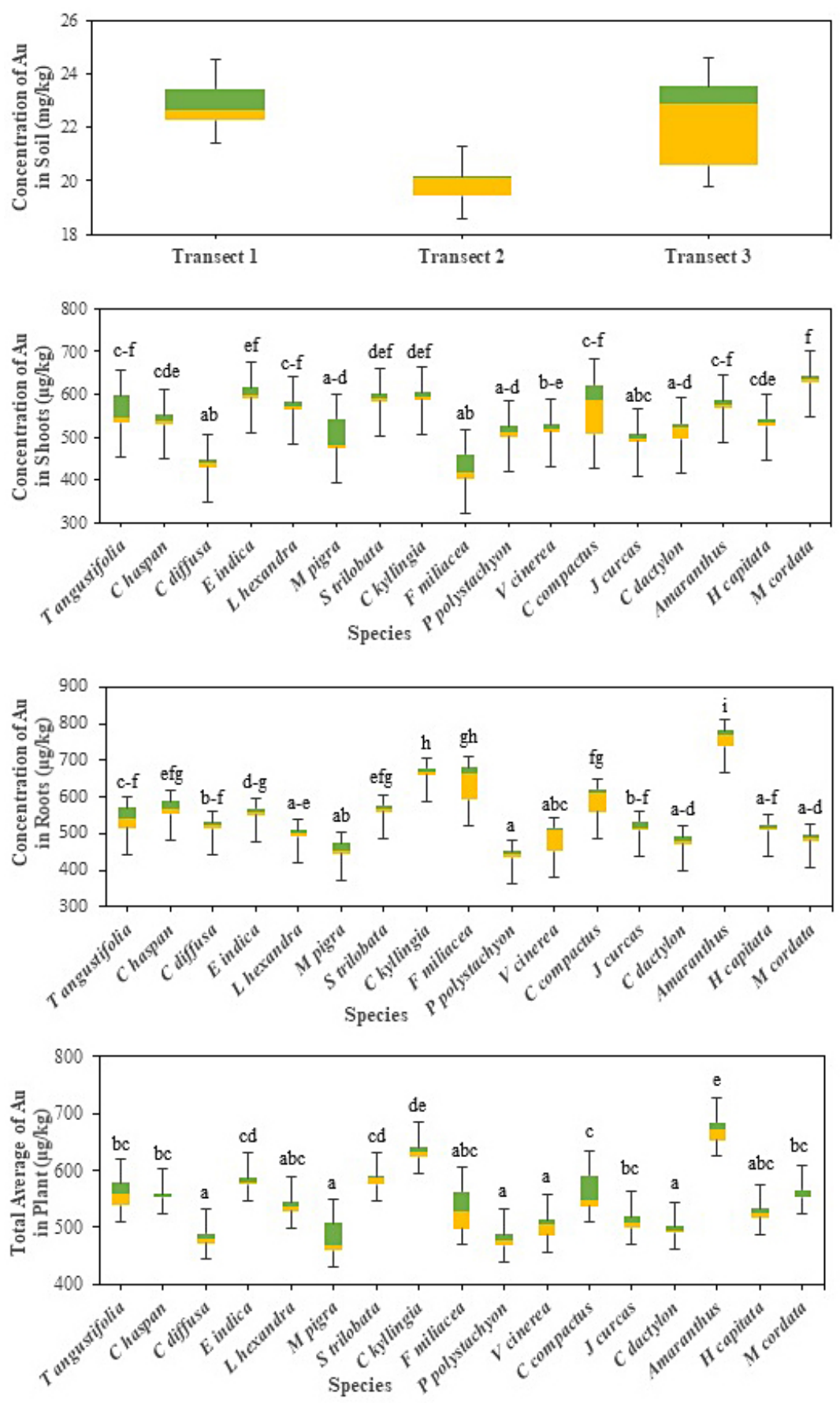

Figure 7. Box-plot graph of gold concentration in soil, shoots, roots, and the average of plants in the area around the tailings dam 
et al. (2017) found 11 species that were able to accumulate gold $(\mathrm{Au})$ with the average concentration of $483.81 \mu \mathrm{g} / \mathrm{kg}$ dry weight. In addition, the results also showed that about 10 species had higher concentration of gold in the shoots than in the roots (Figure 6) suggesting that those plants categorized as metal extractor. These plants have the potential as genetic resources for further study as prospective gold phytomining species in gold mine tailing area.

\section{Biological concentration factor and translocation factor}

The biological concentration factor (BCF) value was measured to understand the plant's ability to accumulate metals from their environment. As shown in Table 2, the BCF values obtained for all plant species were less than 0.1 suggesting that all plants were categorized as lower accumulator of gold. Gold metal is not easily soluble in the soil and is not easily absorbed by plants (WilsonCorral et al., 2012). The plant species with the highest BCF value was Amaranthus sp. (0.0374), and the lowest was $P$. polystachion (0.0203). Even though the differences among the BCF values were not much, but in general they are statistically significant $(\mathrm{P}<0.05)$ with Amaranthus sp. as the most had capacity to mobilize gold from the sediment into the plant tissues (Table 2). The improvement of gold absorption may be facilitated by a chemical assisted by addition some chemical chelate such as cyanide or thiocyanate and/or by application of some micronial agent such as endophytic bacteria as well as fungus (Naila et al., 2019; Sheoran et al., 2016).

The translocation factor (TF) value was varied among the species with 10 plant species had a TF value $>1$, while others had a TF value $<1$ (Table 2). The plants that accumulate metals more in the roots show a TF value $<1$, while a TF value $>$ 1 indicates that metal is accumulated more in the shoots (Mellem et al., 2009). The plant species with the highest TF value was $M$. cordata, while the plant species with the lowest TF value was F. miliaceae. The data of the TF value obtained indicated that most of the plants $(60 \%)$ collected from gold mine tailings dam were categorized as phytoextractor plants.

The plants with the phytoextraction mechanism are expected to have 2 functions; phytoremediation and phytomining (Anderson et al., 2005). The benefit of plant with phytoremediation capacity is that the accumulator plants can remove heavy metal pollutants such as lead, mercury, or other substance such as cyanide from contaminated sites via plant absorption. The benefit of the phytomining capacity is that the plants can absorb valuable metals such as nickel, gold, and platinum and then can be harvested and processed into bio-ore. A major limitation of the phytoextraction process is the bio-availability of valuable metals or elements in the soil. However, there have been several agronomic methods to enhance the availability of metals, such as adding chelates and fertilizers or applying microorganisms (mycorrhiza

Table 2. The BCF and TF value of plants in the area around the tailings dam

\begin{tabular}{|c|c|c|c|c|c|}
\hline No & Species & $\mathrm{BCF}$ & Indicator & TF & Indicator \\
\hline 1 & Amaranthus sp. & $0.0374^{a}$ & Low accumulator & $0.761^{\mathrm{fg}}$ & Phytostabilization mechanism \\
\hline 2 & Typha angustifolia & $0.0297^{b}$ & Low accumulator & $1.060^{\mathrm{bcd}}$ & Phytoextraction mechanism \\
\hline 3 & Cyperus kyllingia & $0.0295^{b c}$ & Low accumulator & $0.891^{\text {defg }}$ & Phytostabilization mechanism \\
\hline 4 & Cyperus compactus & $0.0290^{\mathrm{bcd}}$ & Low accumulator & $0.967^{\text {bcde }}$ & Phytostabilization mechanism \\
\hline 5 & Fimbristylis miliaceae & $0.0287^{\text {bcde }}$ & Low accumulator & $0.702^{\mathrm{g}}$ & Phytostabilization mechanism \\
\hline 6 & Hyptis capitata & $0.0275^{\text {bcdef }}$ & Low accumulator & $1.034^{\text {bcde }}$ & Phytoextraction mechanism \\
\hline 7 & Jatropha curcas & $0.0263^{\text {cdefg }}$ & Low accumulator & $0.935^{\text {cdef }}$ & Phytostabilization mechanism \\
\hline 8 & Mikania cordata & $0.0260^{\text {cdefg }}$ & Low accumulator & $1.301^{\mathrm{a}}$ & Phytoextraction mechanism \\
\hline 9 & Vernonia cinerea & $0.0254^{\text {defgh }}$ & Low accumulator & $1.093^{\mathrm{bcd}}$ & Phytoextraction mechanism \\
\hline 10 & Spagneticola trilobata & $0.0251^{\text {efgh }}$ & Low accumulator & $1.040^{\text {bcde }}$ & Phytoextraction mechanism \\
\hline 11 & Mimosa pigra & $0.0246^{\mathrm{fgh}}$ & Low accumulator & $1.127^{\mathrm{abc}}$ & Phytoextraction mechanism \\
\hline 12 & Cynodon dactylon & $0.0239^{\text {fghi }}$ & Low accumulator & $1.072^{\mathrm{bcd}}$ & Phytoextraction mechanism \\
\hline 13 & Cyperus haspan & $0.0237^{\text {fghi }}$ & Low accumulator & $0.949^{\text {cdef }}$ & Phytostabilization mechanism \\
\hline 14 & Eleusine indica & $0.0232^{\text {ghi }}$ & Low accumulator & $1.081^{\mathrm{bcd}}$ & Phytoextraction mechanism \\
\hline 15 & Commelina diffusa & $0.0216^{\mathrm{gi}}$ & Low accumulator & $0.839^{\text {efg }}$ & Phytostabilization mechanism \\
\hline 16 & Leersia hexandra & $0.0207^{i}$ & Low accumulator & $1.145^{\mathrm{abc}}$ & Phytoextraction mechanism \\
\hline 17 & Pennisetum polystachion & $0.0203^{i}$ & Low accumulator & $1.161^{\mathrm{ab}}$ & Phytoextraction mechanism \\
\hline
\end{tabular}


Table 3. The potential of phytomining of the plants in the area around the tailings dam

\begin{tabular}{|c|c|c|c|c|c|}
\hline \multirow[t]{2}{*}{ No } & \multirow[t]{2}{*}{ Species } & \multirow[t]{2}{*}{ Family } & \multirow{2}{*}{$\begin{array}{c}\text { The average of gold } \\
\text { concentration } \\
(\mathrm{mg} / \mathrm{kg})\end{array}$} & \multirow{2}{*}{$\begin{array}{l}\text { The average of dry } \\
\text { weight biomass } \\
\text { estimation }\left(\mathrm{gr} / \mathrm{m}^{2}\right)\end{array}$} & \multirow{2}{*}{$\begin{array}{c}\begin{array}{c}\text { Potential of } \\
\text { phytomining }\end{array} \\
\text { (Au g/ha) } \\
\end{array}$} \\
\hline & & & & & \\
\hline 1 & Typha angustifolia & Typhaceae & 0.5576 & 5135.80 & $2.8636^{a}$ \\
\hline 2 & Cyperus haspan & Cyperaceae & 0.5569 & 5128.27 & $2.8560^{\mathrm{a}}$ \\
\hline 3 & Eleusine indica & Poaceae & 0.5818 & 4182.97 & $2.4337^{\mathrm{ab}}$ \\
\hline 4 & Cynodon dactylon & Poaceae & 0.4944 & 4319.70 & $2.1358^{\mathrm{abc}}$ \\
\hline 5 & Cyperus compactus & Cyperaceae & 0.5699 & 3133.67 & $1.7868^{\mathrm{abcd}}$ \\
\hline 6 & Hyptis capitata & Lamiaceae & 0.5253 & 3307.43 & $1.7381^{\mathrm{abcd}}$ \\
\hline 7 & Leersia hexandra & Poaceae & 0.5365 & 2423.83 & $1.2994^{\text {bcde }}$ \\
\hline 8 & Spagneticola trilobata & Asteraceae & 0.5799 & 2175.20 & $1.2598^{\text {bcde }}$ \\
\hline 9 & Mikania cordata & Asteraceae & 0.5612 & 1948.10 & $1.0944^{\text {bcde }}$ \\
\hline 10 & Mimosa pigra & Fabaceae & 0.4917 & 1766.57 & $0.8959^{\text {cde }}$ \\
\hline 11 & Pennisetum polystachion & Poaceae & 0.4790 & 1580.83 & $0.7580^{\text {cde }}$ \\
\hline 12 & Commelina diffusa & Commelinaceae & 0.4809 & 1461.37 & $0.7022^{\text {cde }}$ \\
\hline 13 & Fimbristylis miliaceae & Cyperaceae & 0.5320 & 759.10 & $0.4166^{\text {de }}$ \\
\hline 14 & Vernonia cinerea & Asteraceae & 0.5032 & 616.90 & $0.3067^{\text {de }}$ \\
\hline 15 & Cyperus kyllingia & Cyperaceae & 0.6323 & 303.27 & $0.1915^{\mathrm{e}}$ \\
\hline 16 & Jatropha curcas & Euphorbiaceae & 0.5155 & 207.40 & $0.1069^{e}$ \\
\hline 17 & Amaranthus sp. & Amaranthaceae & 0.6675 & 133.43 & $0.0894^{\mathrm{e}}$ \\
\hline
\end{tabular}

and bacteria) to the soil (Sheoran et al., 2016; Naila et al., 2019).

The study carried out by Wilson-Corral et al. (2011) showed that Helianthus annuus and Kalanchoe pinnata (with the addition of chelates) were able to accumulate gold metal up to $10.6-55.6 \mathrm{mg} / \mathrm{kg}$ and $9.53-21.7 \mathrm{mg} / \mathrm{kg}$, respectively. They even calculated the potential value of gold phytomining from previous studies, generating a net profit of around 15098 dollars (Wilson-Corral et al., 2012). However, the most important factor is the amount of income based on the price of the metal mined by the phytomining process. The best metal candidates for the phytomining process are gold, platinum, palladium, and rhodium, because of their high value (Dinh et al., 2022). High metal prices will support the possibility in the spending of chemicals/chelating agent used to increase metal solubility, fertilizers to increase soil productivity, and other agronomic management practices (Handayanto et al., 2017)

\section{Potential of phytomining analysis}

Phytomining is an alternative technology that can be applied for the recovery of valuable elements when conventional mining is not viable economically (Heilmeier \& Wiche, 2020). Bioavailability and solubility of metals are among the main keys for effective phytomining (Piccinin et al., 2007). The potential of phytomining (PP) of the plants in the area around the tailings dam can be seen in the Table 3 .

The results show that the highest potential of phytomining Au were obtained by T. angustifolia (2.8636 g/ha Au dry weight) and C. haspan (2.8560 g/ha Au dry weight), while the lowest were obtained by $J$. curcas $(0.1069 \mathrm{~g} / \mathrm{ha}$ Au dry weight) and Amaranthus sp. (0.0894 g/ha Au dry weight). T. angustifolia, in addition to its higher potential in the phytomining process of gold $(\mathrm{Au})$, it also had phytoextraction ability $(\mathrm{TF}>1)$, while $C$. haspan was categorized as phytostabilizator $(\mathrm{TF}<1)$. In other words, among all the species found in the area around the tailings dam, T. angustifolia was the greatest potential phytoaccumulator plant which has capacity as phytomining agent for gold $(\mathrm{Au})$ on the tailing area. T. angustifolia and C. haspan have been proven to have good adaptability to many heavy metals in contaminated areas and therefore were suggested as hyperaccumulator plants (Chandra and Yadav, 2011; Wirosoedarmo, 2020). In addition, these species also have huge biomass production (Sricoth et al., 2017) which supports the total accumulation of metal extraction for the phytomining program. Another impotent finding in this experiment was that Amaranthus sp. which had the highest $\mathrm{Au}$ accumulation (Figure 7). These plants are categorized as fast growing and have a lot of seeds. Therefore, they may have the potential as genetic resources for further development 
using breeding technology to improve biomass production to support Au phytomining from gold mine tailing.

\section{CONCLUSIONS}

A vegetation analysis from the transects applied around gold mine tailing suggested that there were a total of 17 species obtained predominated by understory plants (dominated by T. angustifolia). The BCF value indicated that all plant species were categorized as low accumulator plants $(\mathrm{BCF}<1)$. In turn, in terms of the TF value, most of the plants $(60 \%)$ were categorized as phytoextractor plants (TF $>1$ ). From all species observed, 10 had higher gold (Au) concentration in the shoots rather than in the roots, making them potential phytomining agents. Among the species, T. angustifolia and C. haspan, were the most prospective species due to their higher values of phytomining potential, biomass production and their other superior parameters. It can be concluded that $T$. angustifolia and $C$. haspan were the most prospective species and potential phytoaccumulator candidates to recover gold from the tailing area with low-grade ores.

\section{Acknowledgements}

The research was funded by the Ministry of Education, Culture, Research, and Technology of the Republic of Indonesia through the Saintek Scholarship Programme in 2018. The authors gratefully acknowledge the Research Center for Limnology-National Research and Innovation Agency of the Republic of Indonesia (BRIN), and IPB University for assistance in analyzing our samples. Also, many thanks to PT. Aneka Tambang (ANTAM Inc.) UBPE Pongkor for supporting research.

\section{REFERENCES}

1. Alimano M, Rinjani R. 2017. Preliminary Research on Extraction of Gold and Other Metals from Vetiver Plants (Vetiveria zizanioides) Using Wet Chlorination Method. J Tekmira. 13(1):45-51. (in Indonesian)

2. Anderson C, Moreno F, Meech J. 2005. A field demonstration of gold phytoextraction technology. Mine Engine. 18: 385-395.
3. Andriya NN, Hamim H, Sulistijorini, Triadiati. 2019. The phytoremediation potential of non-edible oil-producing plants for gold mine tailings. Biodiv. 20(10): 2949-2957.

4. Asati A, Pichhode M, Nikhil K. 2016. Effect of heavy metals on plants: an overview. IJAIEM. 5(3):56-66.

5. Asmayannur I, Chairul, Syam Z. 2012. The Analysis of Understory Vegetation on Jati Emas (Tectona grandis) and Jati Putih (Gmelina arborea) Stand in Andalas University. J Bio Uni And. 1(2):172-177. (in Indonesian)

6. Aththorick TA. 2005. Similarities of Understorey Communities in Several Types of Plantation Ecosystems in Labuhan Batu Regency. J Kom Pen. 17(5):42-48. (in Indonesian)

7. Bali T, Siegele R, Harris AT. 2010. Phytoextraction of Au: uptake, accumulation and cellular distribution in Medicago sativa and Brassica juncea. J Chem Engine. 156:286-297.

8. Chandra R, Yadav S. 2011. Phytoremediation of $\mathrm{Cd}, \mathrm{Cr}, \mathrm{Cu}, \mathrm{Mn}, \mathrm{Fe}, \mathrm{Ni}, \mathrm{Pb}$ and $\mathrm{Zn}$ from aqueous solution using Phragmites cummunis, Typha angustifolia and Cyperus esculentus. Internat J Phytorem. 13(6): 580-591.

9. Chaney R, Baklanov IA. 2017. Chapter Five-Phytoremediation and Phytomining: Status and Promise. Advan in Botani Res. 83:189-221.

10. Dinh T, Dobo Z, Kovacs H. 2022. Phytomining of noble metals - A review. Chemosphere. 286: 131805. Doi: 10.1016/j.chemosphere.2021.131805.

11. Fashola MO, Ngole-Jeme VM, Babalola OO. 2016. Review heavy metal pollution from gold mines: environmental effects and bacterial strategies for resistance. Int J Environ Res Pub Health. 3(11): 1047. doi: 10.3390/ijerph13111047.

12. Ghani A. 2010. Toxic effects of heavy metals on plant growth and metal accumulation in maize (Zea mays L.). Iran J Toxicol. 3(3): 325-334.

13. Gill SS, Tuteja N. 2010. Polyamines and abiotic stress tolerance in plants. Plant Sign Behav. 5:26-33.

14. Guerra-Sierra BE, Guerrero JM, Sokolski S. 2021. Phytoremediation of Heavy Metals in Tropical Soils an Overview. Sustainability. 13: 2574.

15. Hamim H, Hilmi M, Pranowo D, Saprudin D, Setyaningsih L. 2017a. Morphophysiological changes of biodesel producer plants Reutalis trisperma (Blanco) in respons to gold mining wastewater. Pak J Biol Sci. 20:423-435.

16. Hamim H, Violita V, Triadiati T, Miftahudin M. 2017b. Oxidative stress and photosynthesis reduction of cultivated (Glycine max L.) and wild soybean (G. tomentella L.) exposed to drought and paraquat. Asian J Plant Sci. 16(2): 65-77. doi:10.3923/ ajps.2017.65.77 
17. Handayanto E, Nuraini Y, Muddarisna N, Syam N, Fiqri A. 2017. Phytoremediation and Phytomining of Heavy Metal Pollutants. Malang: UB Press. (in Indonesian)

18. Heilmeier H., Wiche, O. 2020. The PCA of Phytomining: Principles, Challenges, and Achievments. Carpat J of Earth and Environ Sci. 15(1):37-42.

19. Herlina, L., Widianarko B., Purnaweni H., Sudarno S., Sunoko H.R. 2020. Phytoremediation of lead contaminated soil using croton (Cordiaeum variegatum) plants. J. Ecol. Eng. 21:107-113. https://doi. org/10.12911/22998993/122238

20. Hilmi M, Hamim H, Sulistyaningsih YC, Taufikurahman. 2018. Growth, histochemical and physiological responses of non-edible oil producing plant (Reutealis trisperma) to gold mine tailings. Biodiv. 19(3): 736-742

21. Indriyani L, Flamin A, Erna E. 2017. Diversity Analysis of Understorey Species in the Jompi Forest. Ecogreen. 3(1):49-58. (in Indonesian)

22. Jaffre, T., Reeves, R., Baker, A.J.M., Schat, H. \& van der Ent, A., 2018. The discovery of nickel hyperaccumulation in the New Caledonian tree Pycnandra acuminata 40 years on: an introduction to a Virtual Issue. New Phytologist. 218:397-400.

23. Krisnayanti BD, Anderson CWN, Sukartono S, Afandi Y, Suheri H, Ekawanti A. 2016. Phytomining for Artisanal Gold Mine Tailings Management. Miner 6:84-94.

24. Lamhamdi M, Bakrim A, Aarab A, Lafont R, Sayah F. 2010. A comparison of lead toxicity using physiological and enzymatic parameters on spinach (Spinacia oleracea) and wheat (Triticum aestivum) growth. Moroccan J Biol. 6-7:64-73.

25. Magurran AE. 1988. Ecological diversity and its measurement. New Jersey (US): Princeton University Press

26. Malayeri BE, Chehregani A, Yousefi N, Lorestani B. 2008. Identification of the hyperaccumulator plants in copper and iron mine in Iran. Pak Jour of Bio Scien. 11: 490-492.

27. Marshall AT, Haverkamp RG, Davies CE, Parsons JG, Gardea-Torresday JL, van Agterveld D. 2007. Accumulation of gold nanoparticles in Brassica juncea. Int J Phyto. 9: 197-206.

28. Mellem JJ, Baijnath H, Odhav B. 2009. Translocation and accumulation of $\mathrm{Cr}, \mathrm{Hg}, \mathrm{As}, \mathrm{Pb}, \mathrm{Cu}$ and $\mathrm{Ni}$ by Amaranthus dubius (Amaranthaceae) from contaminated sites. Jour of Environ Sci and Health, Part A: Toxic/Hazardous Substances and Environmental Engineering. 44(6): 568-575.

29. Naila A, Meerdink G, Jayasena V, Sulaiman AZ, Ajit AB, Berta G. 2019. A review on global metal accumulators-mechanism, enhancement, commercial application, and research trend. Environ Sci and
Poll Res. 1-23.

30. Noviardi R, Karuniawan A, Sofyan ET, Suryatmana P. 2021. Potential of sweet potato (Ipomoea batatas) for gold phytomining from mercury amalgamation tailings. IOP Conf. Ser.: Earth Environ. Sci. 789 012073 doi:10.1088/1755-1315/789/1/012073

31. Odum E P. 1971. Fundamentals of Ecology. Philadephia: W B Sanders Co.

32. Piccinin R C R, Ebbs S D, Reichman S M, Kolev S D, Woodrow I E and Baker A J M. 2007. A screen of some native Australian flora and exotic agricultural species for their potential application in cyanideinduced phytoextraction of gold. Miner Engine. 20:1327-1330

33. Pranoto BSM., Budianta W. 2020. Phytoremediation of Lead $(\mathrm{Pb})$ and Arsenic (As) Contaminated Soil in Artisanal Gold Mining at Selogiri, Wonogiri District, Central Java, Indonesia. Jour of Applied Geo. 5(2):64-72

34. Rodriguez E, Parsons JG, Peralta-Videa JR, CruzJimenez G, Romero-Gonzalez J, Sanchez-Salcido BE, Saupe GB, Duarte-Gardea M, Gardea-Torresdey JL. 2007. Potential of Chilopsis linearis for gold phytomining: using XAS to determine gold reduction and nanoparticle formation within plant tissues. Int J Phytoremediation. 9(2):133-47. doi: 10.1080/15226510701232807

35. Rondonuwu SB. 2014. Phytoremediation of Mercury Waste Using Plants and Reactor Systems. J Ilm Sains. 14(1): 52-59. https://doi.org/10.35799/ jis.14.1.2014.4951 (in Indonesian)

36. Saim, A. K., Ntiri-Bekoh, R., Orleans-Boham, H. Amankwah, R. K. 2020. Gold Phytoextraction by Alocasia macrorrhizos: Implications in Phytomining. Proceedings of 6 th UMaT Biennial International Mining and Mineral Conference, Tarkwa, Ghana, 272-280.

37. Setiawan KA, Sutedjo, Matius P. 2017. Composition of Understorey Types in Revegetation Land Post Coal Mining. J Hut Trop. 1(2):182-195. (in Indonesian)

38. Setyaningsih L, Wulandari AS, Hamim H. 2018. Growth of typha grass (Typha angustifolia) on gold-mine tailings with application of arbuscular mycorrhiza fungi. Biodiv. 19 (2): 504-509. https:// doi.org/10.13057/biodiv/d190218

39. Shahid M, Khalid S, Abbas G, Shahid, N, Nadeem M, Sabir M, Aslam M, Dumat C. 2015. Heavy metal stress and crop productivity. In book: Hakeem KR, 36 editor. Crop Production and Global Environmental Issues. Basel $(\mathrm{CH})$ : Springer International Publishing. pp 1-25.

40. Sheoran V, Sheoran AS, Poonia P. 2009. Phytomining: a review. Min Engine 22(12):1007-1019.

41. Sheoran V, Sheoran AS, Poonia P. 2013. Phytomining 
of gold: A review. Jour of Geo Explor. 128:42-50.

42. Sheoran V, Sheoran AS, Poonia P. 2016. Factors affecting phytoextraction: a review. Pedosphere. 26:148-166.

43. Sricoth T, Meeinkuirt W, Pichtel J, Taeprayoon P, Saengwilai P. 2018. Synergistic phytoremediation of wastewater by two aquatic plants (Typha angustifolia and Eichhornia crassipes) and potential as biomass fuel. Environ Sci Pollut Res Int. 25(6):5344-5358. doi: 10.1007/s11356-017-0813-5.

44. Sunariyati S, Amin M, Hakim L. 2017. Potential accumulation of Gold $(\mathrm{Au})$ in several plant species in the Central Kapuas gold mining area. J Peng Ling Berkel. 1(3):33-42. (in Indonesian)

45. Tangahu BV, Abdullah SRS, Basri H, Idris M, Anuar N, Mukhlisin M. 2011. Review article: a review on heavy metals $(\mathrm{As}, \mathrm{Pb}$, and $\mathrm{Hg}$ ) uptake by plants through phytoremediation. Int $\mathrm{J}$ Chem Engine. $1-31$.

46. Wang YS, Ding MD, Pang Y, Gu XG, Gao LP, Xia T. 2013. Analysis of interfering substances in the measurement of malondialdehyde content in plant leaves. As J Chemist. 25(11):6293-6297.

47. Wei S, Zhou Q, Mathews S. 2008. A newly found cadmium accumulator-Taraxacum mongolium.
J Hazard Mat. 159(2):544-547. doi:10.1016/j. jhazmat.2008.02.052

48. Wilson-Corral V, Anderson C, Rodriguez M, Arenas-Vargas M. 2011. Gold phytomining: Phytoextraction of gold and copper from mine tailings with Helianthus annuus L. and Kalanchoe serrata L. Minerals Eng. 24(13):1488-1494. doi:10.1016/j. mineng.2011.07.014

49. Wilson-Corral V, Anderson CWN, Rodriguez-Lopez M. 2012. Gold phytomining. A review of the relevance of this technology to mineral extraction in the 21st century. J Env Manage. 111: 249-257.

50. Wirosoedarmo R, Anugroho F, Mustaqiman AN, Amanah R, Gustinasari K. 2020. Phytoremediation of chrome in batik industry wastewater using Cyperus haspan. Nanotechnol Environ Engin. 5(2):1-9. doi: 10.1007/s41204-019-0064-4

51. Wolfe AK, Bjornstad DJ. 2002. Why would anyone object? An exploration of social aspect of phytoremediation acceptability. Crit Rev in Plant Sci. 21:429-438.

52. Yoon J, Cao X, Zhou O. 2006. Accumulation of Pb, $\mathrm{Cu}$, and $\mathrm{Zn}$ in native plants growing on contaminated Florida site. Sci of the Tot Env. 368: 456-464. 